\title{
11
}

\section{Mummification of the human body as a vector of social link: The case of Faténaoué (New Caledonia)}

\author{
Frédérique Valentin and Christophe Sand
}

\section{Introduction}

This chapter details mummified bodies that were seated in braided baskets and displayed at the opening of a small rock shelter, on top of a karstic peak dominating an old village situated in the Faténaoué Valley (Témala-Voh, New Caledonia). These bodies call attention to a characteristic of Kanak, and more generally Melanesian, societies: the need for an extended physical connection with ancestors. This trait is exemplified by the burial practices of Ndani (Irian Jaya, Indonesia), Buang and Anga (Papua New Guinea) societies in the present day (Beckett and Nelson 2015; Vial 1936), as well as in the societies of the Torres Strait during the 19th century (Pretty 1969). Over the nearly 3000 years of its prehistoric and traditional Kanak history, the New Caledonia archipelago has seen the development of an exceptional diversity of burial traditions (Sand et al. 2003, 2008). While archaeological studies can identify differences between time periods, there is also clear regional variability in burial practices, body treatments and status-dependent mortuary rituals between contemporaneous communities and chiefdoms (Valentin and Sand 2001, 2008).

In this chapter, the term 'mummification' is defined as the treatment of a corpse aiming at preventing decomposition of soft tissues of the body. Thus a 'mummy' corresponds to human remains with preserved soft tissues (Aufderheide 2003). We will describe the techniques and successive operations leading to the preparation and conservation of mummies in the Kanak society of Témala by using oral history, ethnohistorical written records, archaeological and bioarchaeological data gained from fieldwork undertaken in 2001 at the site of Faténaoué and an examination of photographs of the site dating back to the beginning of the 20th century. This will allow us to highlight the particular vision of the ancestor within this society and to explore its role and place in the context of the New Caledonian micro-regional sociocultural systems.

\section{Written ethnohistorical reports and oral history concerning mummification}

Three first-hand written reports depict the practice of mummification of the human body in New Caledonia. At the end of the 1860s, Patouillet witnesses the smoking of the corpse of a chief in a house in Wagap (Patouillet 1873:170-172). Glaumont, who lived in New Caledonia at the end of the 19th century, records the use of mummification for the chiefs in the Belep Islands 
and in the central chain of Grande Terre. He describes in detail the process. It occurs in a house and comprises perforations of the skin to introduce preservative plant products, desiccation of the body, clothing and make-up of the face (Glaumont 1888:128). Vincent, who stayed in the Houailou region during the 1890s, mentions the contracted position of the smoked body and indicates that the treatment, practised in a house, used to be exclusively for chiefs, but was applied to people of lesser status at the end of the 19th century in the Touho region (Vincent 1895:53).

Other ethnohistorical reports demonstrate the existence of mummies in New Caledonia and the Loyalty Islands. Vieillard, Deplanche and Bourgarel, who stayed in New Caledonia between 1855 and 1867 , mention mummified bodies in open air settings, deposited on the ground or in trees, sometimes in 'a kind of coffin', in the Canala region (Bourgarel 1866:414; Vieillard and Deplanche 1863:63). In 1869, Bonnafont (1871:236-237) mentions uncorrupted bodies wrapped in mats and deposited for several years at the surface of caves and rock shelters in the Loyalty Islands. Father Lambert (1901:285), who lived in New Caledonia during the second half of the 19th century, has observed parts of human bodies with desiccated skin in caves of Isle of Pines. Similar observations were made by Sarasin at the beginning of the 20th century in caves and rock shelters in the north of Grande Terre (Sarasin 1929 [2009:235]; Sarasin and Roux 1917:96), and on Maré and Lifou in the Loyalty Islands (Sarasin and Roux 1917:244, 246, 274, Figure 144). Sarasin has illustrated a mummy placed in a vegetal basket in a crouched position, knees against shoulders, about $70 \mathrm{~cm}$ high, and described it as a 'dry mummy with the skin hard and parchment-like' (Sarasin 1929 [2009, plate 16, Figure 4:233]). This particular mummy seems to be the same one illustrated later by Nevermann (1942:48).

In addition to the written records, oral histories about the north of Grande Terre describe the process of mummification of the human body and the transport of the mummy to its resting place. According to Leenhardt (1947:110-112), the Faténaoué people, who speak languages related to the Poapoâ and Poai (Hienghène) languages and are associated to the Hoot ma Waap customary area, used to travel for several days to transport their dead to a secret place; and smoke the body and make small openings in the body using vegetal spines to remove the bodily fluids. Kasarhérou (1986:3) reports also that the Faténaoué people used to smoke the bodies before transport to the resting place with wooden poles of about $2 \mathrm{~m}$ long, using a technique similar to that used to smoke fish and meat. More specifically, an oral history collected by Gony in 2001 in the Gomen region (fwai language) (Valentin and Gony 2016:14-17) describes two distinct processes to smoke a body in function of the social status of the dead. The process for elites is complicated and performed in several different locations. It includes massaging the body with vegetal oils or leaves; draining of bodily fluids by making small openings in the body; contraction of the body; its smoking (sometimes wrapped in a vegetal envelope); and the use of two vegetal baskets. One is of simple shape and used to transport the mummy to its resting place, as illustrated on engraved bamboos (Dellenbach and Lobsiger 1939:338). The second, made at the resting place, is referred to as an 'armchair', in which the body was seated. The process ends with the placement of the mummy in a secret place, an isolated cavity at altitude. In the Paici-Camuhi customary area (immediately adjacent to the south of Hoot ma Waap area), the desiccated body is placed and conserved on a net stretched between posts near the top of the central post in the chiefly house (Boulay 1990:103). 


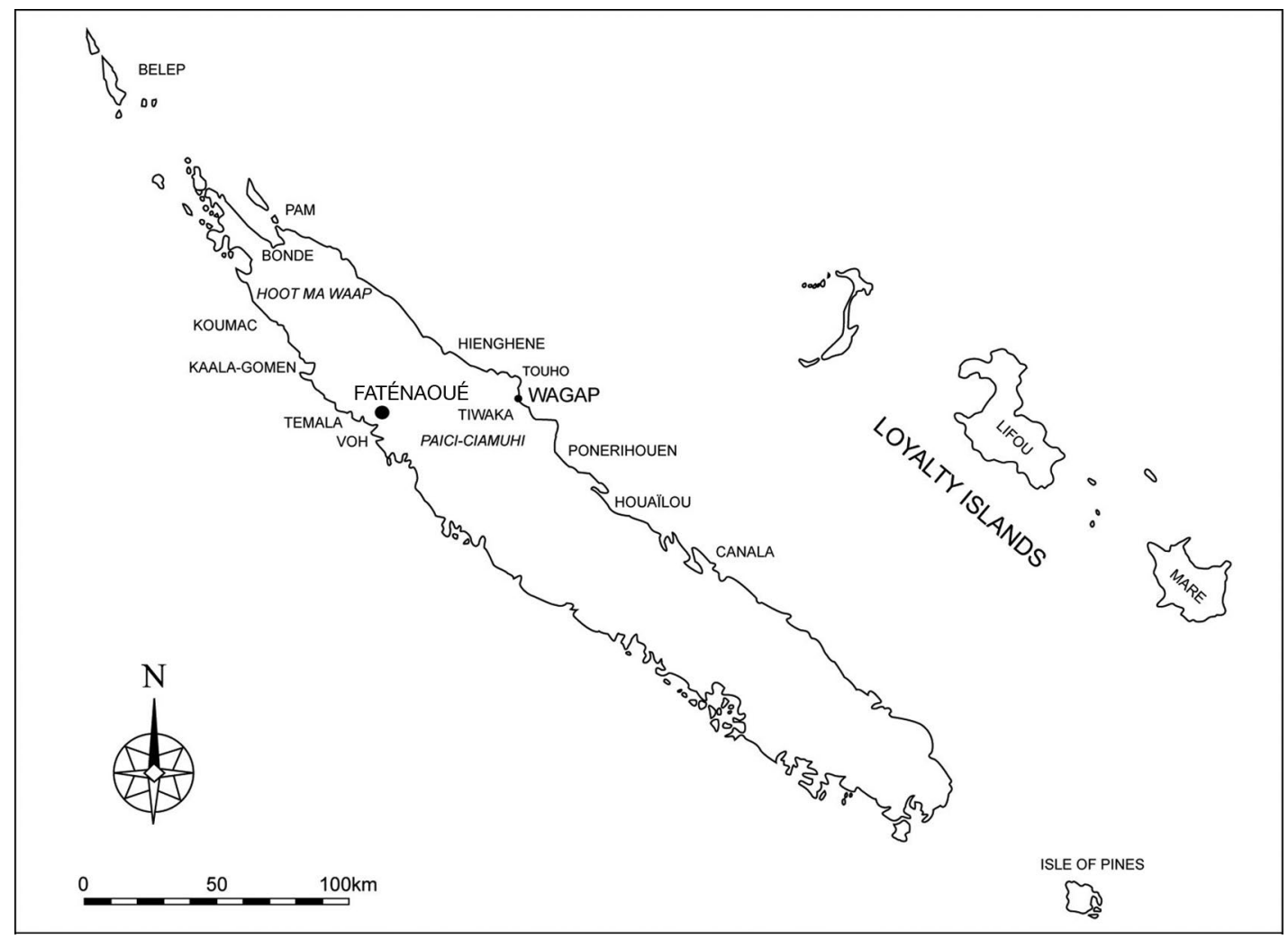

Figure 11.1. Map of New Caledonia with the location of the different sites mentioned in the text. Source: Institute of Archaeology of New Caledonia and the Pacific.

\section{Bioarchaeological study of the Faténaoué mummies}

The Faténaoué site is located in the Témala-Voh region, in the north-western part of Grande Terre, New Caledonia, bordering the Paici-Camuhi customary area to the south (Figure 11.1). The cavity sheltering the mummies is located in the central chain, at an elevation of more than $500 \mathrm{~m}$ above an old Kanak hamlet and about $12 \mathrm{~km}$ in straight line from the mouth of the Témala River, on top of a peak associated to the Mount Tenda Formation (624 m) dominating the Faténaoué Valley.

The site of Faténaoué and the mummies were probably visited by Europeans since the beginning of the French colonisation of Grande Terre in the mid-19th century. A written report describes a visit to the site in December 1938 (Leenhardt 1947) and published photographs have been taken since the 1930s (Brou 1970, 1977; Larsen and Larsen 1960; Leenhardt 1947). We have been able to assemble a series of 10 sets of photographs housed in the New Caledonian Archives at the New Caledonian Museum and in private collections. The photographs were taken over a period of about 70 years, from the middle of the 1930s to the beginning of the 2000s. The photographs of Ernest Lauchlan Sinclair (ANC 139Fi) (Figure 11.2) and E Perkins, the latter being published in 1942 in National Geographic (de Chetelat 1942), are the earliest of the lot. These photographs provide unexpected and complementary data to perform dynamic bioarchaeological analysis of the mummies. Archaeologists studying a site generally observe only the last state of a long succession of transformative actions, particularly in open air sites. Our bioarchaeological field study of the Faténaoué mummies was conducted in 2001, at the request of the North Province of New Caledonia, in agreement with the traditional Kanak landowners. No human remains were displaced/moved while our field observations were undertaken, with the exception of the sampling of soft tissues and bone fragments, as reported in Sand et al. (2016). 
In 2001, two mummies were visible at the entrance of a cavity of limited size ( $4.6 \mathrm{~m} \mathrm{x} 4.6 \mathrm{~m}$, and not more than $1.0 \mathrm{~m}$ high) opening on a small platform $4.4 \mathrm{~m}$ long, located on top of a limestone peak of limited accessibility. Facing the valley, the two bodies were seated, upper and lower limbs flexed, knees against the chest, in a position held by a winding rope as indicated by the constrained position of the shoulders (projecting forwards) and the accumulation of ropes at the feet of both individuals (Figure 11.3). Each body was in a basket, with a third basket behind them and a low stone wall protecting them at the front. The two individuals are adult and rather old, as arthritis lesions were observed at the joints of the skeletons. The northernmost one is male and the sex of the other (in central position) is unknown. This second individual is better preserved and died between 1888 and 1916, as revealed by the colorimetric analysis of a bone fragment (post mortem delay $99+/$ - 14 years, Jean-Noël Vignal, IRCGN, Rosny-sous-Bois, France, pers. comm. 2002). An oral history associated with the site and naming the deceased (Mae Kahouta from Faténaoué and his wife from Hienghène), confirms this early 20th-century date (Kasarhérou 1986). The death of these individuals therefore occurred after the first installation of European settlers in the region, following the opening of the settlements of Koné in 1880, Pouembout in 1883 and Voh a few years later (Merle 1995; Saussol 1979).

The two individuals could have been from the same biological group. They display similar morphological features. Particularly, both are very tall, exceeding $1.8 \mathrm{~m}$ in height, which is a distinctive trait of the men of the Baco region as noticed by the ethnologist Sarasin at the beginning of the 20th century (Sarasin 1916-1917:86). Ancient mitochondrial DNA extracted from bone samples taken from the two individuals show that both do not possess the 9-bp deletion identifying haplogroup B, an Asian-derived lineage found at high frequencies in Polynesian populations (Matisoo-Smith 2016). It also revealed that one of them (the second individual) belongs to the haplogroup Q (Q1), a haplogroup already identified in New Caledonia (Q2) and frequent in several forms in north Melanesia (Friedlaender et al. 2007). Isotopic data measured in bone collagen extracted from fragments sampled from the two individuals indicate that they had a diet relying mainly on vegetal food items, in combination with a few marine products such as shellfish and algae (Herrscher and Valentin 2016).

In 2001, the two bodies were partially skeletonised and displayed comparable distributions of preserved soft tissues. The northernmost body is represented by skeletal elements partially maintained in articulation by desiccated soft tissues surrounding the joints and covering the chest. Remains of ligaments, muscles and skin of brown dark colour are extremely dry, lacking fat and displaying a homogenous and fibrous aspect. The second individual is comprised of skeletal elements in articulation, largely covered by brown, homogenous, fibrous and extremely dry soft tissues, lacking fat. Notably, the skull is covered by remains of soft tissues which present two different layers (skin and muscle) in the neck region. Moreover, the tissues covering the chest are folded, due to the early retraction of the layers underlying the skin, which is a particular feature of desiccated and mummified bodies (Aufderheide and Rodriguez-Martin 1998). No body part was ablated from the bodies, the thoraces were not opened and the necks were not disarticulated on purpose. The bones are unburned and the mummies are characterised by extreme dryness and the loss of lipid in soft tissues. Hair and nails are absent as observed not only in 2001 but also in the earlier photographs. These features suggest in both cases a desiccation perhaps by sun and/or low heat and smoke exposure, as shown by un-flexed extremities of the bodies (implying no contraction of muscles at the extremities) and no explosion of the brain cases (Symes et al. 2008). An early loss of epidermis is also suggested, as hair and nails (elements associated with the epidermis that are absent here) take longer to disintegrate than other soft tissues in natural conditions of decomposition; in this respect, the Faténaoué mummies recall the smoked bodies from the Aseki region in Papua New Guinea (Beckett and Nelson 2015). 


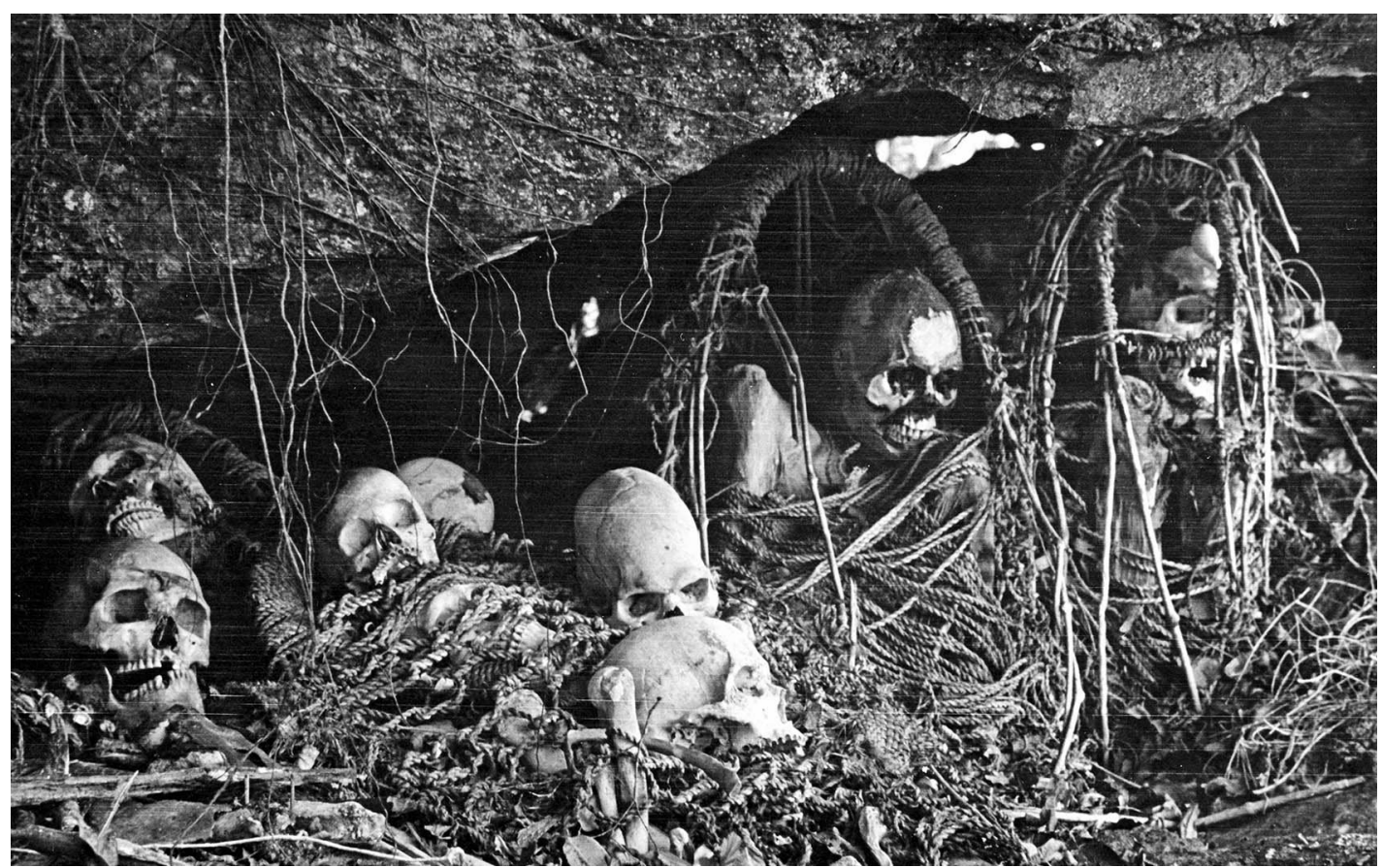

Figure 11.2. View of the Faténaoué mummies at the beginning of the 1930s (courtesy Archives de la Nouvelle-Calédonie-Fonds Ernest Lauchlan Sinclair-139Fi).

Source: Ernest Lauchlan Sinclair.

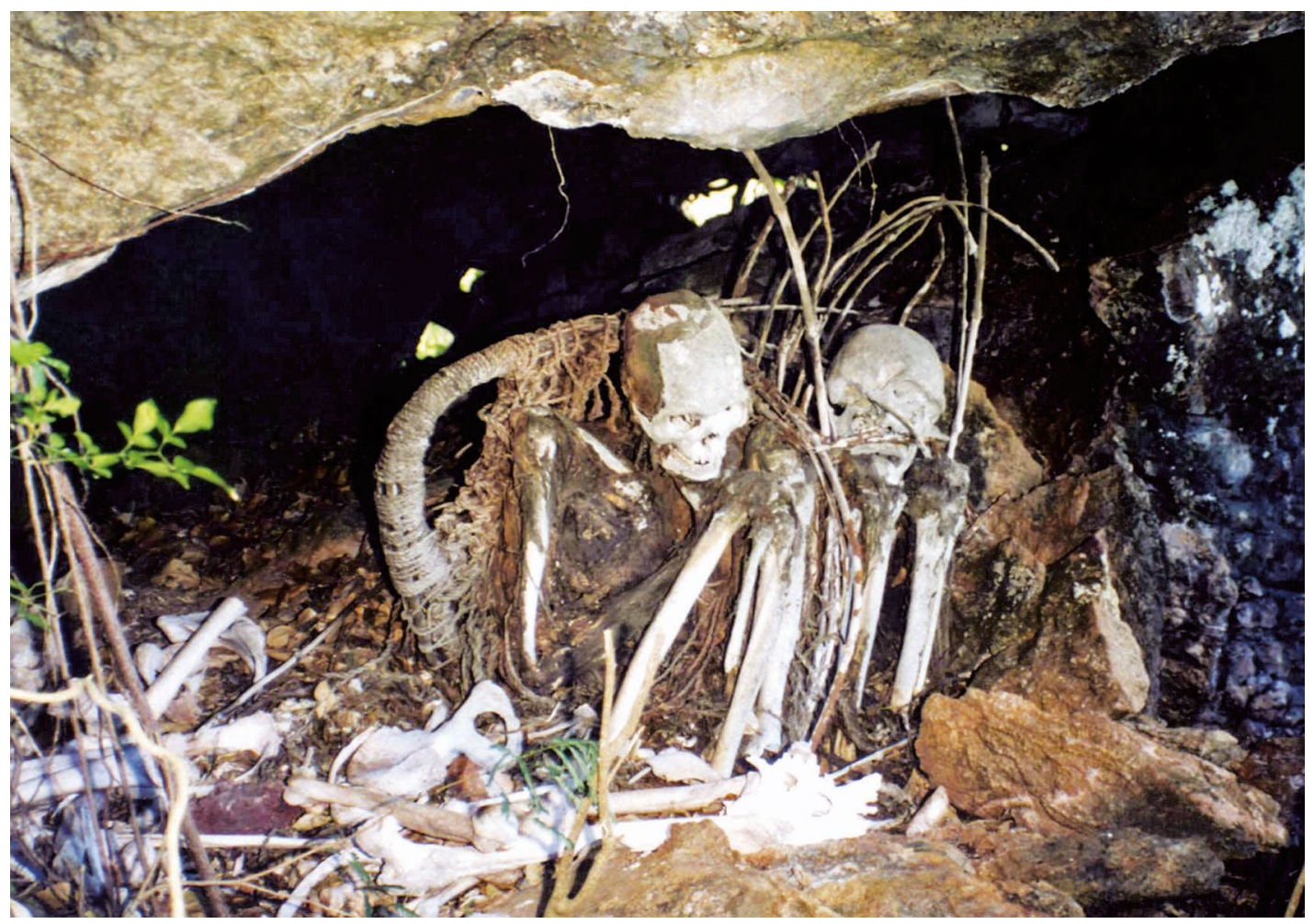

Figure 11.3. The mummies of Faténaoué as they were during the 2001 archaeo-anthropological study. Source: Christophe Sand. 

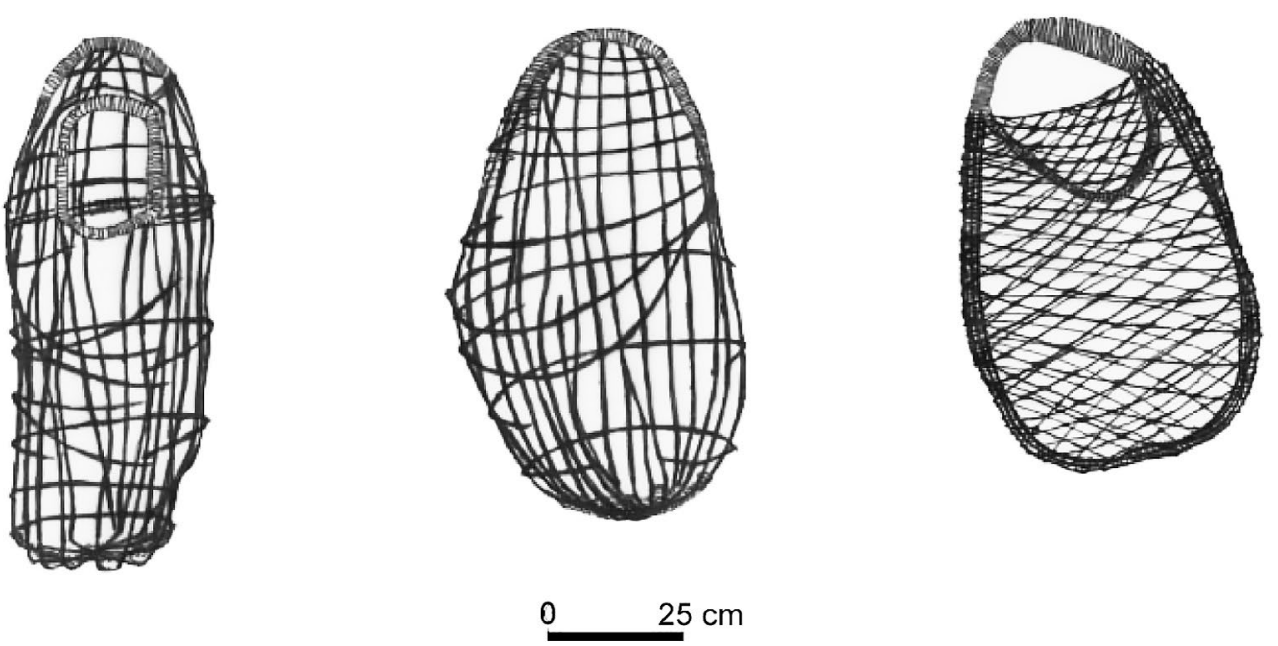

Figure 11.4. The form of the three baskets still visible in the Faténaoué burial shelter.

Source: Christophe Sand.

As mentioned earlier, the Faténaoué mummies are enclosed in baskets. The baskets can be associated with the net style as defined by Balfet (1952), which is comprised of three elements: a net, a frame and a rope used to tie the net to the frame. The frame consists of an assemblage of stems of a vine (Smilax sp.), while the netting and rope are made of coconut fibres (Coco nucifera). The three baskets are of different forms, with variation in the shape of the frame and the presence of handles or openings (Figure 11.4) adorned with shell in at least one case, as testified by Leenhardt's 1938 photographs. Other vegetal elements such as a small vegetal bundle placed between the skull and the knee of the northernmost individual and a wooden pole can be seen on the early photographs. While altered from their original state, these materials do not seem to have been exposed to fire or smoke.

The human remains of at least five individuals, some charred, were scattered at the feet of the two Faténaoué mummies along with various grave goods (Figure 11.3). This assemblage comprises only dry bones among which the cranial extremity is under-represented. It includes both male and female individuals according to the morphology of the coxal bone (Bruzek 2002), all of whom appearing to be relatively old. Our analysis of the photographs (Figure 11.2) indicates that more skeletal elements, especially skulls and bones with desiccated soft tissues still attached, were originally present in the rock shelter. This demonstrates that these scattered bones are what is left from the degradation of at least nine to perhaps 11 other mummies, also placed in baskets. At least three other baskets were identified on the early photographs.

\section{Discussion}

\section{Potential purpose for mummification}

Overall, the bioarchaeological features of the Faténaoué mummies reflect a sequence of actions practised over time and in several distinct locations that reflects the particular vision of the ancestor within this Kanak society from the north of Grande Terre. This sequence conforms in several ways with first-hand written reports and oral history related to the site and other areas of north Grande Terre. The inferred removal of the epidermis can be associated with the massage of the body mentioned in the oral tradition. The flexion of the corpse, knees against chest, is also reported in the oral history and the written records. It was probably done a short time after death 
on a still-supple body. Combined with verticality, the contracted position encourages desiccation and the elimination of decomposition fluids. At Faténaoué, the position was maintained with ropes constraining shoulders and torso, a detail not mentioned in oral histories and written records but documented from other funerary contexts in the north of Grande Terre (Sarasin 1929 [2009]). The desiccation of the bodies at Faténaoué appears to result from the sun and/or low heat and smoke exposure, in agreement with oral histories and written records. No traces of covering clothing or of make-up were identified at Faténaoué, but the bodies were adorned as shell bracelets were seen by Leenhardt in 1938 (Leenhardt 1947). Finally, the mummies were transported to the Faténaoué rock shelter already mummified. Wooden poles were observed at the site, which could have been associated with the transport of the mummies. The large number of mummies that once existed in the site relative to the small size and configuration of the shelter, as well as the absence of absorbing material and combustion remains (except some charred bones) also support this view. However, this does not exclude other activities at the site, like basketmaking as mentioned in oral traditions. The baskets in which the mummies rest do not seem particularly adapted for transport but rather conceived for display. Some of them have a square or rectangular shell-adorned opening placed in front of the face of the mummy.

Comparisons with other mummies from Oceania highlight the uniqueness of the Faténaoué mummies. If the removal of epidermis observed at Faténaoué is a frequent practice in mummification processes of Oceanian populations (Beckett and Nelson 2015; Pretty and Calder 1998), other features appear specific to New Caledonia: no body part was removed from the bodies, the thoraces were not opened, the necks were not disarticulated on purpose and there is no apparent effort to re-establish a living human appearance, as documented, for example, for Torres Straits mummies (Bonney and Clegg 2011; Flower 1879; Pretty and Calder 1998) or funerary mannequins of Malekula, Vanuatu (Speiser 1923 [1996]). The use of basket containers at Faténaoué also differs from the stretchers used to present mummies in the Torres Strait during the 19th century (Pretty 1969) and the armchairs used today in the Anga societies of Papua New Guinea (Beckett and Nelson 2015).

The purpose of making mummies may also be different at Faténaoué. Cases of temporarily preserving the physical living appearance of the dead, and the abandonment, inhumation or cremation of the prepared body subsequent to funerary ceremonies, are reported for Australia and the Torres Strait Islands (Bonney and Clegg 2011; Pretty and Calder 1998). In Polynesian societies (except perhaps in New Zealand, where mummies were placed in rock shelters; Orchiston 1971; Simmons 1967), the preservation or mummification of the body was also a component of the funerary system, as it appears it had, in some instances, an intermediate function in a complex sequence of activities surrounding the physical remains of the dead (Aufderheide 2003; Handy 1927; Linton 1925; Maureille and Sellier 1996).

Considering the staging observed at Faténaoué, we think that the purpose of the mummification of human bodies in the Faténaoué society was probably to obtain long-lasting media to ensure extended networks of social relationships for future generations. At first glance, the Faténaoué living/dead relationship suggests avoidance. Ropes hamper the bodies, baskets enclose them and the mummies are placed in an isolated and secret location, apart from the dwelling areas, thus establishing a distance from the living and the present. The physical remains of the dead could have inspired fear or respect. As elsewhere in Melanesia, fear is an emotion mentioned in the New Caledonian ethnographic literature (Leenhardt 1930 [1980]:217), and regulations related to prohibition (taboo) limit close physical living/dead interactions to selected members of the society (Leenhardt 1947; Sarasin 1929 [2009]). However, three aspects support our hypothesis of the establishment of a dead/living social link not only to 'contemplate the landscape and address his blessing' (Leenhardt 1947:111) but for future mediations. The Faténaoué mummies were placed at an elevated location dominating the settlement, faces turned towards the living 
(Leenhardt 1947:111). The relation between the face, the eyes and the opening in the basket confers to the mummy a form of 'beingness', a being possessing the faculty of perception and communication despite the fact its living human appearance was not re-established. Finally, the mummies were apparently produced to be durable, to resist time and potentially to be active, even at distance, for a duration exceeding the time of those who made them.

\section{Place in the regional Kanak sociocultural system}

The New Caledonian practice of mummification of the dead appears to be localised mainly in the northern part of Grande Terre. More precisely, it appears to overlap the Hoot ma Waap customary area, which is also characterised by a particular mask tradition (Guiart 1987), with an extension to the south in the Paici-Camuhi area. The practice was witnessed during the 19th century in the regions of Wagap (Patouillet 1873:170-172), Touho (Vincent 1895:53), and Belep (Glaumont 1888), and mummies were seen not only in the Faténaoué Valley but also in the Khongo Valley (Routhier 1957), and in caves in the Koumac region (Sand and Bolé 2012; Sarasin 1929 [2009]). The practice does not seem present with the same intensity in other New Caledonian regions, confirming Leenhardt's hypothesis of a custom of the north of Grande Terre that becomes rare south of Ponérihouen (Leenhardt 1930 [1980:217]), except maybe in the Canala region (Yves-Béalo Gony, pers. comm. 2013). By contrast, the mummies observed in the Loyalty Islands appear to be the result of a natural mummification process (Bonnafont 1871). In caves on Lifou Island, still supple and fat bodies with nails and hair, dating to the beginning of Christian conversion era, are extended, wrapped in mats and placed in wooden containers (Sand et al. 1995; Valentin and Bolé 2001). Written sources also mention that body embalming was not part of the funerary practice on Lifou Island (Hadfield 1920).

The Faténaoué mummies do not appear to express a short-lived mortuary phenomenon but rather a multigenerational practice associated with a particular group and developed over a long period in the extended sociocultural region of northern Grande Terre. Available chronological information from direct dating on bone and oral history naming the deceased indicate that the practice, still active at the turn of the 20th century, ceased only after European colonisation. The variation in the level of degradation of mummies and baskets and the number of mummified individuals suggest that the practice was carried out earlier and most probably predated the 19th century (Sand et al. 2016).

The intensity of the practice of mummification in the Voh-Témala region, with mummies in the Khongo Valley (Routhier 1957), and at least nine to 11 mummies on top of Faténaoué peak and others in cavities towards the base of the same peak (Kasarhérou 1986), might result from a twofold sociopolitical phenomenon: an identity affirmation at a border zone and an indigenisation process, developed by newcomers in the region as episodes of friction occurred. During the first half of the 19th century, Paicî populations expanded from the east coast to the Voh-Témala region, leading to conflicts between local settlers and Kanak foreigners from the south-east (cf. Bensa 2000). During the second half of the 19th century, changes in the Faténaoué chiefdom related to the European colonisation of the region occurred, as recorded by the ethnographer J Guiart (1987:90-92):

Le clan des maitres du sol à Hwatenewe [Faténaoué] aurait été à l'origine dit: Pwaduya ma Bwanehot. Il aurait été par la suite remplacé par les Pwacili Hmaè [clan composite], originaires de Koné. (The clan of the masters of the ground at Hwatenewe [Faténaoué] was possibly originally named: Pwaduya ma Bwanehot. It appears it subsequently got replaced by the Pwacili Hmaè [a composite clan], originating from Koné.)

The chief Hmaè Kahouta of Faténaoué belonged to this Pwacili Hmaè clan and was one of the last Kanak mummified in the Voh-Témala region and his body was transported to the top of the karstic peak. 


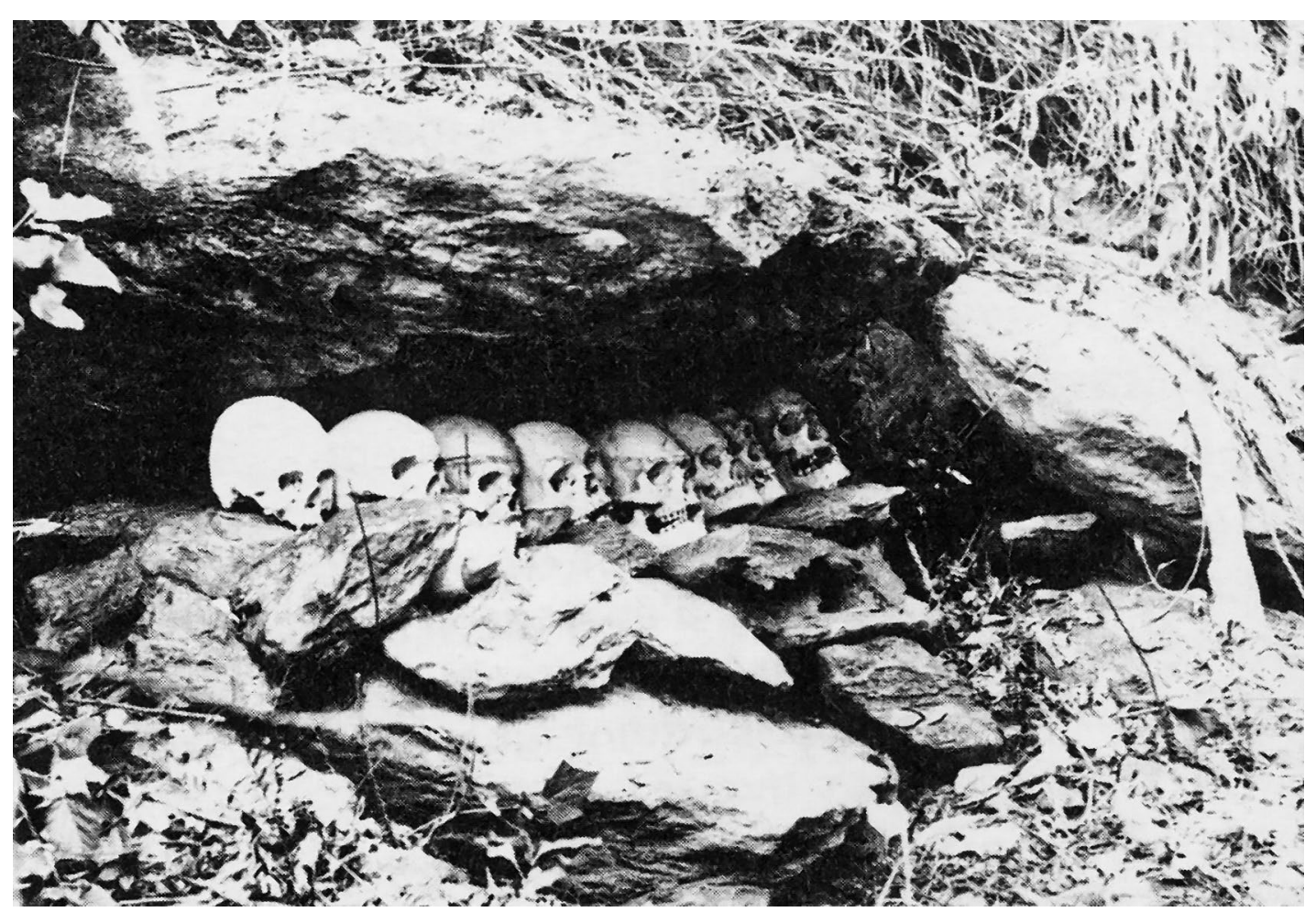

Figure 11.5. Alignment of skulls in a Kanak funerary outcrop (courtesy Archives du Musée Néo-Calédonien). Source: Origin unknown: image from Archives du Musée Néo-Calédonien.

\section{Conclusion}

To conclude, the practice of mummification and the form of relation between mummies and survivors described here do not appear to be a phenomenon introduced from outside New Caledonia. Several facets of the treatment are fully inscribed in the mortuary system built by traditional Kanak societies during the second millennium CE, particularly in the north of Grande Terre (Valentin and Sand 2001, 2008). Notably, inhumations are set apart from the living space, placed at its edge, as for example at Pwanitio, in the Tiwaka Valley (Sand 1997), or in remote and rocky areas inappropriate for cultivation, or in the forest (Saussol 1990:24). The treatment of the skulls is an aspect reflecting the final stage of another complex mortuary process: they were exposed, aligned and the face turned outside, on or behind a low wall, protected by a canoe or at the opening of a rocky outcrop in several regions of Grande Terre (Bourgarel 1865; Leenhardt 1930 [1980]; Sarasin and Roux 1917; Vieillard and Deplanche 1863 [2001]) (Figure 11.5).

Mummification of the human body and mummies from a localised area, overlapping the Hoot ma Waap and the Paicî-Camuhi customary areas of New Caledonia, are therefore elements of a cultural package related to the traditional Kanak complex (Sand et al. 2003, 2008). It is the identity and/or social marker of a particular group that required the inscription of the deceased's name in the genealogical memory and its integration in the legitimation of claims to land at a time where groups' reconfiguration was at play (Saussol 1979). 


\section{Acknowledgements}

We would like to thank the Dounehote family for allowing us access to the Faténaoué burial shelter in 2001 and for permitting us to collect samples for scientific analysis on the mummies. The administrative permit was delivered by the President of the Northern Province to the (then) Department of Archaeology of New Caledonia. The study was fulfilled through funding accorded by the Northern Province and the CNRS UMR 7041. We would also like to thank the Archives of New Caledonia, the Museum of New Caledonia and the Viale family for giving us access to archival data related to the Faténaoué mummies.

\section{References}

Aufderheide, AC. 2003. The scientific study of mummies. Cambridge: Cambridge University Press.

Aufderheide, AC and C Rodriguez-Martin. 1998. Cambridge encyclopedia of human paleopathology. Cambridge: Cambridge University Press.

Balfet, H. 1952. 'La vannerie: Essai de classification'. L’Anthropologie 56:259-280.

Beckett, RG and AJ Nelson. 2015. 'Mummy restoration project among the Anga of Papua New Guinea'. Anatomical Record 298:1013-1025. doi.org/10.1002/ar.23139.

Bensa, A. 2000. 'Le chef kanak. Les modèles et l'histoire'. In En pays kanak, edited by A Bensa and I Leblic. Paris: Editions de la Maison des sciences de l'homme. doi.org/10.4000/books. editionsmsh.2771.

Bonnafont. 1871. 'Des sépultures aux îles Loyalty'. Bulletins de la Société d'Anthropologie de Paris 6 (6):236-240. doi.org/10.3406/bmsap.1871.4465.

Bonney, $\mathrm{H}$ and M Clegg. 2011. 'Heads as memorials and status symbols: The collection and use of skulls in the Torres Strait Islands'. In The bioarchaeology of the human head: Decapitation, deformation and decoration, edited by M Bonogofsky. Gainsville, FL: University Press of Florida. doi.org/10.5744/ florida/9780813035567.003.0002.

Boulay, R. 1990. La maison kanak. Marseille: Editions Parenthèses.

Bourgarel, A. 1865. Notes ethnographiques sur la Nouvelle-Calédonie et dépendances. Paris.

Bourgarel, A. 1866. 'Des races de l'Océanie française, de celles de la Nouvelle-Calédonie en particulier, deuxième partie: Caractères extérieurs, mœurs et coutumes des Néo-Calédoniens'. Mémoires de la Société d'Anthropologie de Paris II:375-416.

Brou, B. 1970. Mémento d'histoire de la Nouvelle-Calédonie, Préhistoire et protohistoire, antiquité et moyen âge. Nouméa: Société Calédonienne d'Editions.

Brou, B. 1977. Préhistoire et société traditionnelle de la Nouvelle-Calédonie. Publications de la Société d'Etudes Historiques de Nouvelle-Calédonie 16. Nouméa: Société d'Etudes Historiques de NouvelleCalédonie.

Bruzek, J. 2002. 'A method for visual determination of sex, using the human hipbone'. American Journal of Physical Anthropology 117:157-168. doi.org/10.1002/ajpa.10012.

de Chetelat, E. 1942. 'War awakened New Caledonia'. The National Geographic Magazine 82 (1):31-55.

Dellenbach, M and G Lobsiger. 1939. 'Quelques scènes de la vie sociale, religieuse et matérielle des NéoCalédoniens, gravées sur bambous'. Archives suisses d’Anthropologie générale 8 (3-4):336-350. 
Flower, WH. 1879. 'Illustrations of the mode of preserving the dead in Darnley Island and in South Australia'. The Journal of the Anthropological Institute of Great Britain and Ireland 8:389-395. doi.org/10.2307/2841081.

Friedlaender, JS, FR Friedlaender, JA Hodgson, M Stoltz, G Koki, G Horvat, S Zhadanov, TG Schurr and DA Merriwether. 2007. 'Melanesian mtDNA Complexity'. PLoSOne 2:e248. doi.org/10.1371/ journal.pone.0000248.

Glaumont, G. 1888. 'Usage, mœurs et coutumes des Néo-Calédoniens'. Revue d'Ethnographie 7:73-141.

Guiart, J. 1987. Mythologie du masque en Nouvelle-Calédonie. Publication de la Société des Océanistes 18. Paris: La Société des Océanistes.

Hadfield, E. 1920. Among the natives of the Loyalty group. London: Macmillan.

Handy, ESC. 1927. Polynesian religions. B.P. Museum Bulletin 79. Honolulu: Bishop Museum.

Herrscher, E and F Valentin. 2016. 'Analyses isotopiques et comportements alimentaires des défunts de Faténaoué. In Les momies de Faténaoué/Hwatenewe (Voh, Province Nord). Etude archéologique et anthropologique d'un site funéraire kanak ancien, edited by C Sand, F Valentin and B Gony, 85-91. Arkaeologia Pacifika 3. Nouméa: Institut d'archéologie de la Nouvelle-Calédonie et du Pacifique.

Kasarhérou, E. 1986. 'Compte-rendu de la mission effectuée à Tieta du 7 au 14 avril 1986'. Unpublished manuscript. Service des Musées et du Patrimoine de la Nouvelle-Calédonie, Nouméa.

Lambert, (le Père). 1901. Mours et superstitions des Néo-Calédoniens. Paris: Maisonneuve.

Larsen, M and H Larsen. 1960. La cyprée d'or, expédition Nouvelle-Calédonie. Neuchâtel: A la Braconnière.

Leenhardt, M. 1930 [1980]. Notes d'ethnologie Néo-Calédonienne. Travaux et mémoires de l'Institut d'ethnologie 8. Paris: Institut d'Ethnologie.

Leenhardt, M. 1947. 'Sépultures Néo-Calédoniennes'. Journal de la Société des Océanistes 3:110-112. doi.org/10.3406/jso.1947.1570.

Linton, R. 1925. Archaeology of the Marquesas Islands. B.P. Bishop Museum Bulletin 23. Honolulu: Bishop Museum. Reprint 1971, New York: Kraus Reprint Co.

Matisoo-Smith, E. 2016. 'Analyse de l'ADN ancien et affinités génétiques des défunts de Faténaoué. In Les momies de FaténaouélHwatenewe (Voh, Province Nord). Etude archéologique et anthropologique d'un site funéraire kanak ancien, edited by C Sand, F Valentin and B Gony, 75-83. Arkaeologia Pacifika 3. Nouméa: Institut d'archéologie de la Nouvelle-Calédonie et du Pacifique.

Maureille, B and P Sellier. 1996. 'Dislocation en ordre paradoxal, momification, décomposition: observations et hypothèses'. Bulletins et Mémoires de la Société d'Anthropologie de Paris 8 (3-4):313-327. doi.org/10.3406/bmsap.1996.2451.

Merle, I. 1995. Expériences coloniales. La Nouvelle-Calédonie (1853-1920). Paris: Belin.

Nevermann, H. 1942. Kulis und Kanaken, Forscherfahrten auf Neukaledonien und in den Neuen Hebriden. Braunschweig: G. Wenzel und Sohn.

Orchiston, DW. 1971. 'Maori mummification in protohistoric New Zealand'. Anthropos 66 (5/6):753-766.

Patouillet, J. 1873. Trois ans en Nouvelle-Calédonie. Paris: E. Dentu.

Pretty, GL. 1969. 'The Macleay Museum: Mummy from the Torres Straits: A postscript to Elliot Smith and the diffusion controversy'. Man 4 (1):24-43. doi.org/10.2307/2799262. 
Pretty, GL and A Calder. 1998. 'Mummification in Australia and Melanesia'. In Mummies, disease and ancient cultures, edited by TA Cockburn, E Cockburn and TA Reyman, 289-307. Cambridge: Cambridge University Press. doi.org/10.1017/CBO9781139878340.017.

Routhier, P. 1957. Carte géologique de la Nouvelle-Calédonie et notice explicative. Feuille n³ VohHienghène 1/100 000e. Paris: Ministère de la France d'Outre-mer, ORSTOM (Office de la recherche scientifique et technique outre-mer).

Sand, C. 1997. 'Variété de l'habitat ancien en Nouvelle-Calédonie: Étude de cas sur des vestiges archéologiques du Centre-Nord de la Grande Terre’. Journal de la Société des Océanistes 104 (1):39-66. doi.org/10.3406/jso.1997.2012.

Sand, C and J Bolé. 2012. 'Visite de deux sites de sépultures dans le domaine de Karst de la Commune de Koumac (Province Nord)'. Unpublished report. Nouméa: Institut d'archéologie de la NouvelleCalédonie et du Pacifique.

Sand, C, J Bolé and A Ouetcho. 1995. Contribution à la reconstitution de la préhistoire des îles Loyauté, premiers résultats des fouilles archéologiques de 1994-1995, Lifou, Maré, Ouvéa. Les Cahiers de l'Archéologie en Nouvelle-Calédonie 5. Nouméa: Institut d'archéologie de la Nouvelle-Calédonie et du Pacifique.

Sand, C, J Bolé and A Ouetcho. 2003. 'Prehistory and its perception in a Melanesian Archipelago: The New Caledonia example’. Antiquity 77 (297):505-519. doi.org/10.1017/S0003598X00092565.

Sand, C, J Bolé, A Ouetcho and D Baret. 2008. Parcours archéologique. Deux décennies de recherches du Département Archéologie de Nouvelle-Calédonie (1991-2007). Les Cahiers de l'Archéologie en Nouvelle-Calédonie 17. Nouméa: Institut d'archéologie de la Nouvelle-Calédonie et du Pacifique.

Sand, C, F Valentin and B Gony (eds). 2016. Les momies de Faténaoué/Hwatenewe (Voh, Province Nord). Etude archéologique et anthropologique d'un site funéraire kanak ancien. Arkaeologia Pacifika 3. Nouméa: Institut d'archéologie de la Nouvelle-Calédonie et du Pacifique.

Sarasin, F. 1916-1917. 'Etude anthropologique sur les Néo-Calédoniens et les Loyaltiens. Première partie: Les caractères extérieurs'. Archives Suisses d'Anthropologie générale 2 (1-2):83-103.

Sarasin, F. 1929 [2009]. Ethnographie des Kanak de Nouvelle-Calédonie et des Îles Loyauté (1911-1912). Paris: Ibis Press.

Sarasin, F and J Roux. 1917. La Nouvelle-Calédonie et les Iles Loyalty. Bâle: Georg \& co.

Saussol, A. 1979. L'Héritage. Essai sur le problème foncier mélanésien en Nouvelle-Calédonie. Paris: Société des Océanistes. doi.org/10.4000/books.sdo.563.

Saussol, A. 1990. 'Le pays kanak'. In La maison kanak, edited by R Boulay, 21-30. Marseille: Editions Parenthèses.

Simmons, DR. 1967. 'A note on the lake Hauroko burial'. Journal of the Polynesian Society 76 (3):257, $367-368$.

Speiser, F. 1923 [1996]. Ethnology of Vanuatu. An early twentieth century study. Bathurst: Crawford House Press.

Symes, SA, CW Rainwater, EN Chapman, DR Gipson and AL Piper. 2008. 'Patterned thermal destruction of human remains in forensic setting'. In The analysis of burned human remains, edited by CW Schmidt and SA Symes, 15-54. London: Academic Press. doi.org/10.1016/B978-0123725103.50004-6. 
Valentin, F and J Bolé. 2001. 'Etude expérimentale de sépultures sur sites sans prélèvement des ossements. Résultats préliminaires des analyses paléobiologiques et des pratiques funéraires des sites de Nonimé, Mucaweng et Hnajoisisi à Lifou (Iles Loyauté)'. Unpublished internal report. Nouméa: Département Archéologie du Service des Musées et du Patrimoine de Nouvelle-Calédonie.

Valentin, F and B Gony. 2016. 'La pratique de la momification en Nouvelle-Calédonie, informations ethno-historiques et données de traditions orales'. In Les momies de FaténaouélHwatenewe (Voh, Province Nord). Etude archéologique et anthropologique d'un site funéraire kanak ancien, edited by C Sand, F Valentin and B Gony, 11-21. Arkaeologia Pacifika 3. Nouméa: Institut d'archéologie de la NouvelleCalédonie et du Pacifique.

Valentin, F and C Sand. 2001. 'Inhumations préhistoriques en Nouvelle-Calédonie'. Journal de la Société des Océanistes 113 (2):27-41. doi.org/10.4000/jso.1579.

Valentin, F and C Sand. 2008. 'Prehistoric burials from New Caledonia'. Journal of Austronesian Studies $2(1): 1-30$.

Vial, LG. 1936. 'Disposal of the dead among the Buang'. Oceania 7 (1):64-68. doi.org/10.1002/j.18344461.1936.tb00378.x.

Vieillard, E and E Deplanche. 1863 [2001]. Essai sur la Nouvelle-Calédonie. Paris: Challamel. Réédition Paris: L'Harmattan.

Vincent, JBM. 1895. Les Canaques de la Nouvelle-Calédonie, esquisse ethnographique. Paris: Challamel. 
This text is taken from Archaeologies of Island Melanesia: Current approaches to landscapes, exchange and practice, edited by Mathieu Leclerc and James Flexner, published 2019 by ANU Press, The Australian National University, Canberra, Australia.

doi.org/10.22459/TA51.2019.11 